
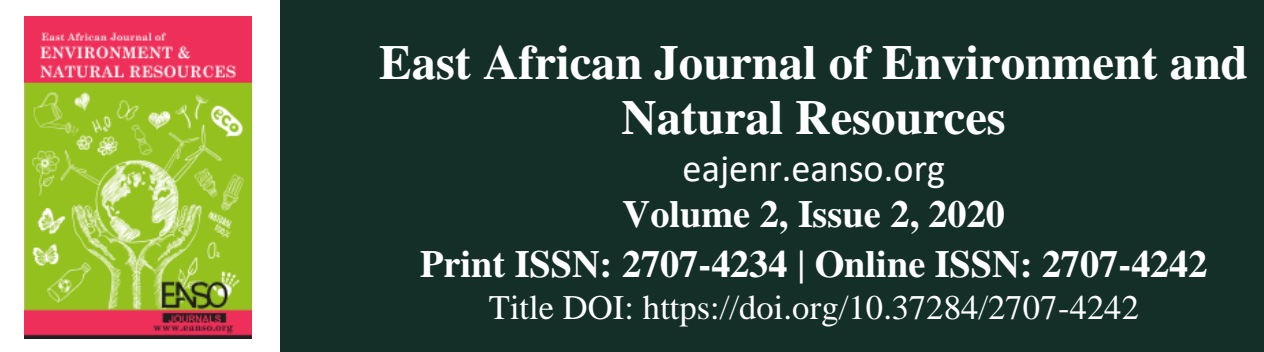

Original Article

\title{
Evaluation of Seagrass and Seaweed Species Diversity, Abundance, and Human Activities Endangering their Existence at Indian Ocean Shore at Kigamboni in Dar es Salaam City, Coastal Zone of Tanzania
}

\author{
Canisius John Kayombo ${ }^{1,2, *}$, Gudrun Barnabas ${ }^{1}$ \& Kivuyo Likinguraine ${ }^{2}$ \\ ${ }^{1}$ Department of Botany, College of Natural and Applied Sciences, University of Dar es Salaam, Tanzania \\ ${ }^{2}$ Forestry Training Institute, Olmotonyi. P. O. Box 35091, Dar es Salaam, Tanzania. \\ *Author for Correspondence email: kayombo33@yahoo.co.uk or kayombocanisius@ gmail.com \\ * ORCID: https://orcid.org/0000-0002-8149-895X
}

Article DOI: https://doi.org/10.37284/eajenr.2.2.174

\section{Date Published: ABSTRACT}

26 June 2020 An evaluation of seagrass and seaweed species diversity, abundance, and the human activities endangering their existence were conducted at the Kigamboni

Keywords: Indian ocean shore in Dar es Salaam city. The study aimed to determine the

Seagrass and Seaweed

Species,

Diversity,

Abundance,

Human Activities,

Endangering. abundance, diversity of seagrasses and seaweeds and to identify human activities undertaken in the study area. A transect was set within the study area where plots of $10 \mathrm{~m} \mathrm{x} 10 \mathrm{~m}\left(100 \mathrm{~m}^{2}\right)$ were established at an interval of $100 \mathrm{~m}$. The encountered seagrass and seaweed species were identified for their scientific names to species level and whenever it was not possible, a specimen was collected and taken to the University of Dar es Salaam Herbarium (DSM) for identification. The species were also counted and recorded as per their number of stems. H' was applied to calculate the Shannon Wiener Index of Diversity. Also, relative abundance (RA) was calculated. A total of 17 species from 14 genera were identified. The calculated H' was 2.0309, an implication of high seagrass and seaweed species diversity. The identified human activities were fishing and swimming. Of those activities, bait collection (33.89\%) was the most dominant while swimming had $33.33 \%$, fishing had $16.67 \%$ and marine gravel had $11.11 \%$. Kigamboni ocean shore comprises of high species diversity of seagrass and seaweed species, facing severe damage from human disturbances. This study recommends for sustainable management of the ocean shore through education, protection strategy to ensure the survival of the existing seagrasses and seaweed species. 


\section{APA CITATION}

Kayombo, C., Komba, L., \& Kashindye, A. (2020). Climate Change Adaptation Strategies among Tobacco Small Scale Growers at Kiloleli Village in Sikonge District, Tanzania. East African Journal of Environment and Natural Resources, $2(2), 1-9$. https://doi.org/10.37284/eajenr.2.2.149

\section{CHICAGO CITATION}

Kayombo, Canisius, Lambert Komba, and Almas Kashindye. 2020. "Climate Change Adaptation Strategies Among Tobacco Small Scale Growers at Kiloleli Village in Sikonge District, Tanzania”. East African Journal of Environment and Natural Resources 2 (2), 1-9. https://doi.org/10.37284/eajenr.2.2.149.

\section{HARVARD CITATION}

Kayombo, C., Komba, L. and Kashindye, A. (2020) "Climate Change Adaptation Strategies among Tobacco Small Scale Growers at Kiloleli Village in Sikonge District, Tanzania”, East African Journal of Environment and Natural Resources, 2(2), pp. 1-9. doi: 10.37284/eajenr.2.2.149.

\section{IEEE CITATION}

C. Kayombo, L. Komba, and A. Kashindye, "Climate Change Adaptation Strategies among Tobacco Small Scale Growers at Kiloleli Village in Sikonge District, Tanzania”, EAJENR, vol. 2, no. 2, pp. 1-9, May 2020.

\section{MLA CITATION}

Kayombo, Canisius, Lambert Komba, and Almas Kashindye. "Climate Change Adaptation Strategies Among Tobacco Small Scale Growers at Kiloleli Village in Sikonge District, Tanzania”. East African Journal of Environment and Natural Resources, Vol. 2, no. 2, May 2020, pp. 1-9, doi:10.37284/eajenr.2.2.149.

\section{INTRODUCTION}

Seagrasses are plants that live in saltwater (Richmond, 2002). They evolved from land plants and today there are over 50 species of seagrasses in the world (Roldon et al., 2016). Seagrasses have flowers, roots, and specialized cells that transport nutrients within a plant making them similar to land plants and different from algae or seaweeds (Bolton et al., 2007). Seagrasses can be seen as dried brown leaves washed up on beaches or as grass beds on intertidal flats and the sandy bottoms of a coastal lagoon. They present floral-like herbaceous angiosperms adapted to rigorous salinity, immersion, occasional desiccation, anchorage on the seabed, and hydrophilic pollination (Richmond, 1995). Worldwide, there are 58 seagrasses species of which about 12 species are known to exist on the western side of the Indian Ocean. The species of the seaweed, among others, include: Thalassia hemprichii, Halophila ovalis, Enhalus acoroides, Halophila stipulacea, Zostera capensis, Cymodecea rotundata, Cymodecea serrulata, Thalassodendron ciliatum, Halodule wrightii, $H$. univervis and Suringodium isoetifolium (Richmond, 2002).

The history of the seaweeds in the East African shore entails the coastal environment as their suitable habitat (McHugh, 2003). In the Indian ocean, relationships show that the Kenyan flora produces a distinct grouping of seaweeds from Tanzania, Madagascar, Mozambique and the Indian Ocean coast of South Africa, somewhat separated from the floras of the rest of the Indian ocean (Bolton et al., 2007). Seaweeds are commonly found on rocky shores in Mangals, seagrass beds, coral reefs, beaches, mudflats, and lagoon. In the intertidal zone, rocky shores support more productive and extensive seaweed population than sandy beaches or mudflats (Oliveira et al. 2005).

Seaweeds are benthic organisms and normally attached to rocky sub-strata. The seaweeds are usually being affected by the ocean current bathing the shore (De la Torre-Castro, 2006; Obuid-Allah et al., 2015). Due to the intermittent supply of the warm waters in the shorelines, this condition is unsuitable for the marine plants to survive (Lubke $\&$ Moor, 1998). Seaweeds are found throughout the world's ocean and seas; of all the seaweeds none is known to be poisonous; Seaweeds are used in many marine times for industrial applications and as fertilizers (Guiry, 2014). Seaweeds are far more complex organisms than generally realized, many have specialized tissues and growth forms. Seaweeds have complicated sex in which many of them are producing sex pheromones (chemicals that attract females or male gametes) with many different types of sex organs (Guiry, 2014). Research on seaweeds and seagrasses diversity of 
the Indian Ocean conducted during the nineteenth century and early part of the twentieth century provide information that tells the diversity of the seagrasses and seaweeds to be high and favourable in the Indian Ocean (Wafar et al., 2011). Seaweeds are macroscopic plants abundant in the littoral (coastal) region of the seashore, as well as the sunlit sub-littoral (Sambamurty, 2005). They belong to the group of algae structurally simple plants lacking conductive tissue and hence without true leaves, stem or roots, and simple reproductive structures (Richmond, 2002). They are distributed worldwide in the sea, in the freshwater, and the moist situations on land (Wiencke et al., 2006). Algae can be multicellular or unicellular, and reproduction in algae is both asexually and sexually forms (Sambamurty, 2005). According to Richmond (2002), the seaweeds area grouped into three major divisions which are Chlorophyta, Phaeophyta, and Rhodophyta.

Chlorophyta (green algae), these are characterized by their grass-green colour resulting from the predominance of the green pigment (chlorophyll) some species in this group include Enteromorpha ramulosa, Ulva pulchra, U. reticulate, U. pertusa, $U$. fasciata, Rhizoclonium grande, Cladophora saviniace, Chaetomorpha crassa and Anadyomene wrigghtii. Phaeophyta (Brown Algae), most species are brown such as Dictyota crispate, Spatoglossum asperum, Sargassum polycystum, and Hermophysa cuneiformis. Rhodophyta (red algae), this comprises of mainly pink, red to purplish (occasionally green or brown) colour algae due to a combination of the red pigment.

\section{Distribution and Ecology of Seagrass and Seaweeds (Algae)}

According to Watson et al. (1993) and De la TorreCastro and Rönnbäck (2004) seagrasses are a unique group of flowering plants that grow in the shallow coastal waters of most continents. Seagrasses can form vast aggregations, or meadows, which alter the flow of water, nutrient cycling, and food web structure of the local environment Seagrasses are broadly distributed in most of the world's oceans and seas, including the Black and Caspian Seas (Watson et al., 1993). Also, it has been known that the global distribution of seagrasses extends up within the Arctic Circle, where they are present in northern Russia, Norway, and Alaska (Watson et al., 1993). Seagrass has also been recorded as far south as New Zealand (De la Torre-Castro \& Rönnbäck, 2004). Seagrasses have evolved the ability to grow completely submerged by seawater, and have an underwater pollination system (UNDP, 2014). They can cope with saline water and have rooting structures that allow them to withstand the movement of water (Hemminga \& Duarte, 2000).

The deepest living seaweeds are some species of red algae. Others have adapted to live in tidal rock pools. In this habitat, seaweed must withstand rapidly changing temperature and salinity and even occasional drying (Wiencke et al., 2006).

\section{Diversity of Seagrass and Weed Species}

Seagrasses are marine angiosperm widely distributed in both tropical and temperate coastal water creating one of the most productive aquatic ecosystems on earth (Gullstrom et al., 2002). Due to high primary production and complex habitat structure, seagrasses beds support a variety of benthic, demersal and pelagic organism in which this means that many fish and shellfish species, including those of commercial interest, are attracted to seagrasses habitat (Gullstrom et al., 2002). Seagrasses are unique plants that flower underwater and have colonized all but the most polar seas. There are about 60 species of seagrass globally. Seagrasses grow under sea ice as well as adjacent to coral reefs. They live in shallow water along exposed coasts and sheltered lagoons and estuaries (Sambamurty, 2005). The leaf area index of seagrasses, tropical rainforests, and temperate rainforests can reach 20 square feet $(1.8 \mathrm{~m} 2)$ of leaf area per one square foot $(0.09 \mathrm{~m} 2)$ of the ground area (Reymolds, 2018). The following are some of the seagrasses found in Tanzania and Kenya's Indian Ocean: $H$. uninervis, $H$. wrightii, $S$. isoetifolium, Cymodocearot undata, C. serrulata, T. ciliatum, Z. capensis, Enhalus acoroides, Halophila minor, $H$. ovalis, $H$. stipulacea and Thalassia hemprichii (Ochieng \& Erttemeijer, 2003). 


\section{Seagrass and Seaweed Species Abundance}

Both seaweeds and seagrasses are much more diverse than any other marine plants; a host of species colonize the East Africa aquatic. Seaweeds and seagrasses are abundantly distributed in the Indian Ocean, seaweeds and seagrasses communities show no seasonal dynamism because the temperature is described as one of the primary factors controlling the growth of seaweeds and seagrasses (Gersun, 2014). Whilst it is evident that seaweeds and seagrasses are present in a wide range and number of species in marine and freshwater (Llewellyn and Airs, 2010).

\section{Seagrasses and Weeds Disturbances}

Seagrasses beds are often subjected to stress resulting from natural and human activities. Seaweeds farming has been hypothesized to affect seagrasses beds through shading and competition for nutrients in the water, chemical abrasion by algal fronds, trampling, and removal of shoots by farmers as well as excretion of hydrogen peroxide and halogenated compounds by algae (Lyimo et al., 2006). Besides, an increase in the tourism industry targeting the beaches in the region plays a great role in seaweeds and seagrasses disturbance in the Indian Ocean. The Indian Ocean, in Tanzania, consists of relatively high species of seagrasses and weeds varying from place to place in the Indian Ocean.

Kigamboni seashore as a part of Tanzania's Indian ocean is rich in seagrass and seaweed species that are inadequately documented. This study aimed to assess seagrass and weed species diversity, abundance, and anthropogenic disturbances at the Kigamboni ocean shore in Dar es Salaam city. This study meant to evaluate the seagrasses and weed species diversity and the human activities endangering their existence at the Kigamboni ocean shore in Dar es Salaam city. The research questions were; what is the seagrasses and weeds diversity at Kigamboni ocean shore? (Indicator(s): identified seagrasses and weeds species; what are the seagrasses and seaweeds species abundance? (Indicator (s): number of individuals/ stems; and what are the existing human activities to the seagrasses and weeds? (Indicator (s): identified activities in the study site).

\section{MATERIAL AND METHODS}

\section{Description of Study Site}

The study was conducted at the Kigamboni ocean shore in Dar es Salaam city. Kigamboni ocean shore is linked by the Kigamboni Bridge to the Kurasini area and by the ferry to Kivukoni and the central business district (Mhagama, 2016). It is situated at $6.3 \mathrm{~km}$ from the Tanzania Posts Corporation headquarters. Kigamboni is situated at the coordinates $6^{0} 49^{\prime} 0^{\prime \prime} \mathrm{S}, 39^{0} 19^{\prime} 0^{\prime \prime} \mathrm{E}$ (Frohlich et al., 2005). The latitude of Kigamboni is -6.8167 , the longitude is 39.3167 (Frohlich et al., 2005).

The rainfall is bimodal with a period of short rains between October and December (Peterson \& Vose, 2016). The driest month is August with $23 \mathrm{~mm}$ of rain and most precipitation is experienced in April averaging $251 \mathrm{~mm}$. The average annual temperature is $25.9{ }^{\circ} \mathrm{C}$. About $1089 \mathrm{~mm}$ of precipitation falls annually. The mean daily temperature is $26^{\circ} \mathrm{C}$ with a variation of $4{ }^{\circ} \mathrm{C}$ and a daily range of $8{ }^{\circ} \mathrm{C}$. The temperature in February averages $27.9^{\circ} \mathrm{C}$ which is the warmest month and July is the coldest month with temperature averaging $23.8^{\circ} \mathrm{C}$ (Peterson \& Vose, 2016).

\section{Data Collection}

A transect of $1 \mathrm{~km}$ with a width of $10 \mathrm{~m}$ was set in the study area along which the observed seagrass and weeds were identified for their scientific names in the field and where was not possible, a sample was collected using plant press and taken to the University of Dar es Salaam for identification. The sampling method involved selecting only a small section of the large area yet produces an accurate representative sampling of the biotic and abiotic parts of that community (Baello, 2016). The identified seagrasses and weeds were also counted for their number of stems and their frequencies. The found human activities were recorded.

\section{Data Analysis}

Shannon Wiener Index of Diversity (H') was applied to calculate the index of diversity (Shannon and Wiener 1949): $H^{\prime}=-\sum$ (pilnpi); where: $H^{\prime}=$ Shannon Wiener value; pi $=$ Proportion of the species; $\ln =$ Natural logarithm. The $H^{\prime}$ is suitable for combining both species richness and evenness 
and less affected by sample size compared to other indexes.

Relative abundance (RA) of species was calculated through; $\mathrm{RA}=\frac{\sum \mathrm{ni}}{\sum \mathrm{N}}$, where; $\mathrm{RA}=$ relative species abundance; $\sum=$ summation; ni $=$ number of stems of each species; $\mathrm{N}=$ overall stems of all species in the study area.

Human activities frequency percentage: the anthropogenic activities were analyzed by applying descriptive and inferential statistics (Kothari, 2004). $\% \mathrm{~F}=\frac{\sum \mathrm{n}}{\sum \mathrm{N}} \times 100 \%$ Where $\% \mathrm{~F}=$ percentage of occurrence; $\sum=$ summation; $\mathrm{n}=$ total frequency per species in the sampled area; $\mathrm{N}=$ overall occurrence of all species in the sampled area.

\section{RESULTS AND DISCUSSION}

\section{Seaweeds and Seagrasses Species Diversity}

The existing biological organisms are formed of various species forming diversity. A total number of 17 seaweeds and seagrasses species and 13 genera belonging to 10 families were identified at the Kigamboni ocean shore (Table 1). The identified species H' was 2.0309 (Table 1), an implication of high seaweed and seagrass species diversity. Typical diversity index entailing high diversity ranges from 1.5 and 3.5 in the tropics, even though exceptionally can go beyond 3.5 (Obuid-Allah et al., 2015). The seagrass and weeds with the highest $H^{\prime}$ ranked from $0.3534 \pm 0.2743$, the moderate was from $0.2569 \pm 0.2264$, while the lowest had an H' of between $0.0892 \pm 0.0245$.

Table 1: Seaweed and Seagrass species abundance, relative abundance, frequency and $H^{\prime}$

\begin{tabular}{lllll}
\hline Scientific Name & Abundance & Relative abundance & Frequency & Diversity (H') \\
\hline Chaetomarpha spaghetti & 221 & 1.4345 & 3 & 0.0608 \\
Gracilaria salicornia & 1884 & 12.2297 & 3 & 0.2569 \\
Halodule beaydettei & 2142 & 13.9045 & 3 & 0.2743 \\
Halophila ovalis & 183 & 1.18792 & 1 & 0.0526 \\
Padina gymnospora & 368 & 2.3888 & 3 & 0.0892 \\
Sarconema filiforme & 70 & 0.4543 & 2 & 0.0245 \\
Sargassum cristaefolium & 138 & 0.89581 & 1 & 0.0422 \\
Sargassum ilicifolium & 240 & 1.5579 & 2 & 0.0648 \\
Sargassum oligocystum & 83 & 0.5387 & 2 & 0.0281 \\
Syringodium isoetifolium & 1496 & 9.7111 & 2 & 0.2264 \\
Thalassodendron ciliatium & 4156 & 26.9782 & 2 & 0.3534 \\
Tilopteris mertensii & 83 & 0.5387 & 2 & 0.0281 \\
Turbanaria turbinate & 116 & 0.7530 & 2 & 0.0368 \\
Ulva fascinate & 170 & 1.1035 & 2 & 0.0497 \\
Ulva pertusa & 111 & 0.7205 & 4 & 0.0355 \\
Ulva reticulate & 237 & 1.53846 & 5 & 0.0642 \\
Zostera capensis & 3707 & 24.0636 & 4 & 0.3427 \\
Totals & $\mathbf{1 5 4 0 5}$ & $\mathbf{1 0 0}$ & $\mathbf{4 3}$ & $\mathbf{2 . 0 3 0 9}$ \\
\hline
\end{tabular}

Species Abundance and Relative Abundance

Abundance entails the total number of stems or biological organisms (Gersun, 2014). The study revealed an abundance of 15,405 for the identified seaweeds and seagrasses. The results indicated that the seagrass and weeds were widely distributed in the study area. It has been stated that there is a great relationship between the abundance and distribution in a locality (Tiorve et al., 2008; Llewellyn and Airs, 2010). The seagrasses and seaweed species that were highly abundant also had the highest relative abundance. Thosodema ciliatum (24.90) and Zostera capensis (24.06) were 
ranked as the highest in terms of relative abundance followed by Halodule beaydettei (13.90), Gracilaria salicornia (12.23) and Syringodium isoetifolium (9.71) as the moderate and the rest were the least (Table 1).

\section{Human Activities}

Human activities are undertakings conducted in an ecological area. Four types of human activities were identified at Kigamboni Sea Shore during this study. Those were; bait collection, swimming, fishing, and marine gravel collection (Table 2). The activities were observed to have caused severe effects on the existence of seaweeds and seagrasses species in the area. Bait collection seemed to pose great impacts on the species followed by fishing, marine gravel collection, and swimming. This was because the community around the Kigamboni Indian Ocean depended on bait collection as a source of catching fish. Seagrasses beds were often subjected to stress resulting from natural and human activities; it has been hypothesized to be highly affecting seagrasses beds (Lyimo et al., 2006). Other researchers have stated that also, an increase in the tourism industry targeted the beaches in the region play a great role in seaweeds and seagrasses disturbance in the Indian Ocean (De la Torre-Castro, 2006). The identified human activities types were four. Bait collection was the most occurred activity (38.89\%) followed by swimming (33.33\%), fishing (16.6\%), and marine gravel collection (11.11\%) (Table 2). The most occurred activity did not mean the most damaging one, as it depends on the disturbance severity.

Table 2: Type of activities identified in the study area

\begin{tabular}{llll}
\hline $\begin{array}{l}\text { S/ } \\
\text { N }\end{array}$ & $\begin{array}{l}\text { Types of } \\
\text { activity }\end{array}$ & Frequency & Percentage \\
\hline 1 & Bait collection & 7 & $38.89 \%$ \\
2 & Fishing & 3 & $16.67 \%$ \\
3 & Swimming & 6 & $33.33 \%$ \\
& Marine gravel & & \\
4 & collections & 2 & $11.11 \%$ \\
& Total & $\mathbf{1 8}$ & $\mathbf{1 0 0 . 0 0 \%}$ \\
\hline
\end{tabular}

\section{CONCLUSION AND RECOMMENDATIONS}

Kigamboni ocean shore in Dar es Salaam city has a high diversity of seagrasses and seaweed species. Some of them were found to be the most dominant of all other species to include Gracilaria salicornia and Thalassodendron siliatium. Subsequently, the Indian Ocean of Tanzania is very important for the lives of the surrounding community, thus affecting the seaweeds and seagrasses damage resulted from massive human activities conducted by the adjacent community. The community among other activities they were involved in collecting the gravel along the coast and fishing using canoes that were found to disturb the marine species diversity.

Grounded on the importance of the Kigamboni seashore, this study recommends the introduction of alternative income-generating activities (IGAs) which will generate income without damaging the ocean shore. These activities are for example ecotourism, provision of education to the community on ocean shore conservation for sustainable environment and development, upgrading the programmers of involving the local community in protecting the sea and equal distribution of sea resource benefits to the local communities' sustainable management of the coast and protection of the ocean shore is encouraged.

\section{ACKNOWLEDGEMENT}

Individuals and organizations provided moral and material support during data collection and analysis. First and foremost, the study team is thankful to the Almighty God, who enabled them to be healthy throughout the study carrier. The FTI, Olmotonyi academic administration made the literature available throughout the study period and the University of Dar es Salaam Herbarium (DSM), specifically Mr. Frank Mbago who offered the study team with an identification guide of seaweed and seagrass species during this study. 


\section{REFERENCES}

Abubakari L U and MutieA M 2011Microalgae Species Biodiversity and Abundance and their Potential for Biofuel in Kenya.Journal of Limnology \&Oceanographypp2-15.

Bolton, J. J., Oyieke, H. A., \& Gwada, P. (2007). The seaweeds of Kenya: checklist, history of seaweed study, coastal environment, and analysis of seaweed diversity and biogeography. South African journal of botany, 73(1), 76-88.

De la Torre-Castro, M. (2006). Humans and seagrasses in East Africa: a social-ecological systems approach. Doctoral dissertation. Institutionen för systemekologi.

De la Torre-Castro, M. \& Rönnbäck, M. (2004). Between humans and seagrasses-an example from tropical East. African Ocean and Coastal Management, 47, 361-387.

Frohlich, J., Niedermeier, W. and Luginsland, H.D. (2005) The Effect of Filler-Filler and FillerElastomer Interaction on Rubber Reinforcement. Composites: Part A, 36, 449460.

Gersun, L. (2014). The abundance and diversity patterns of seaweed communities on natural and artificial substrata at Sodwana Bay, South Africa. Doctoral dissertation. The University of Cape Town.

Guiry, M. D. (2014). The seaweed site: information on marine algae. Retrieved from Seaweed, available at http://www.seaweed.ie.

Gullström, M., de la Torre Castro, M., Bandeira, S. O., Björk, M., Dahlberg, M., Kautsky, N., ... \& Öhman, M. C. (2002). Seagrass ecosystems in the western Indian Ocean. AMBIO: a Journal of the Human Environment, 31(7), 588-596.

Hemminga, M. A., \& Duarte, C. M. (2000). Seagrass ecology. Cambridge University Press.

Kothari, C. R. (2004). Research Methodology. Methods and Techniques, Second Edition. New Delhi: New Age International Publishers.
Llewellyn, C. A., \& Airs, R. L. (2010). Distribution and abundance of MAAs in 33 species of microalgae across 13 classes. Marine drugs, 8(4), 1273-1291.

Lubke, R., \& De Moor, I. J. (Eds.). (1998). Field guide to the Eastern \& Southern Cape coasts. Rondebosch, SA: University of Cape Town Press.

Lyimo, T. J., Mvungi, E. F., Lugomela, C., \& Björk, M. (2006). Seagrass biomass and productivity in Seaweed and Non-Seaweed Farming areas in the East Coast of Zanzibar. Western Indian Ocean Journal of Marine Science, 5(2), 141-152.

McHugh, D. J. (2003). A guide to the seaweeds industry. FAO Fisheries Technical Paper 441. Rome: Food and Agriculture Organization of the United Nations.

Mhagama, H. (2016). Five Districts of Dar es Salaam. The United Republic of Tanzania.

Obuid-Allah, A. H., El-Wakeil, K. F. A., El-Shimy, N. A., Mohamoud, M. A. \& Omer, M. Y. (2015). Impacts of Construction of the New Assiut Barrages on Zooplankton Community Structure Inhabiting Nile River at Assiut Egypt. International Journal of Advanced Research, 3(9) 588-598.

Ochieng, C. A., \& Erftemeijer, P. L. A. (2003). The seagrasses of Kenya And Tanzania. World Atlas of Seagrasses, 82-92.

Oliveira, E. C. D., Österlund, K., \& Mtolera, M. S. (2005). Marine plants of Tanzania: A field guide to the seaweeds and seagrasses. Sida/Department for Research Cooperation, SAREC

Peterson, T. C. \& Vose, R. S. (2016). Maps and Time Series Temperature and Precipitation Maps Global Climate Report. National Centre for Environmental Information.

Reynolds, P.L. (2018). Seagrass and seagrass beds. https://ocean.si.edu/ocean-leaf/plantsalgae/seagrass-and-seagrass-beds; accessed on $9^{\text {th }}$ June 2020. 
East African Journal of Environment and Natural Resources, Volume 2, Issue 2, 2020

Article DOI: https://doi.org/10.37284/eajenr.2.2.174

Richmond, M. D. (1995). A Field Guide to the in Environmental Science and Bio/Technology, 6(1-3), 95-126. Seashores of Eastern Africa. Ambio, 24(7/8), 522-525.

Richmond, M. D. (2002). A Field Guide to the Seashores of Eastern Africa and the Western Indian Ocean Islands, 2nd edition. Sida.

Roldan, B. A., Suerte, J. S., Lee, F. D. V., Baello, J. A. V., \& Javier, S. N. (2016,). Identification

and distribution of Talitridean amphipod species found on the inland islands of Lake Taal, Philippines. In 51st BIOTA Annual National Convention and Scientific Sessions

Sambamurty, A. V. S. S. (2005). A textbook of algae. IK International Pvt. Limited.

Shannon, C. E. \& Wiener, W. (1949). The Mathematical Theory of Communication. University of Illinois Press. The United States of America.

Tiorve, E., Kunu, E., Polce, C. \& Tiorve, K.M. (2008). Species area relationship: Separating the effect of species abundance and spatial distribution. Journal of Ecology. 96: 11411151.

United Nations Development Programme (UNDP). (2014). Seagrasses of the world. Biodiversity environment. United Nations Environment Programme (UNEP).

Wafar, M., Venkataraman, K., Ingole, B., Khan, S. A., \& LokaBharathi, P. (2011). State of knowledge of coastal and marine biodiversity of Indian Ocean countries. PLoS One, 6(1).

Watson, R. A., Coles, R. G., \& Long, W. L. (1993). Simulation estimates of annual yield and landed value for commercial penaeid prawns from a tropical seagrass habitat, northern Queensland, Australia. Marine and Freshwater Research, 44(1), 211-219.

Wiencke, C., Clayton, M. N., Gómez, I., Iken, K., Lüder, U. H., Amsler, C. D., ... \& Dunton, K. (2007). Life strategy, ecophysiology and ecology of seaweeds in polar waters. Reviews 